\title{
China's Rhetorical Challenge to the US-led Order in the Asia-Pacific and the Response of Regional States
}

\author{
Jae Jeok Park
}

This article first investigates China's 'delegitimizing rhetoric' aimed at undermining a US-led regional order as a means of its balancing behavior against the United States at a low level. Second, as a case study the article looks into the US strategy of strengthening its alliances and security partnerships, which has been an essential component of retaining a US-led hegemonic order in the region, and China's response to it. Third, the article examines how regional states have been attempting to carve out their space in the rhetorical confrontation between the United States and China.

Key Words: United States, China, Delegitimizing Rhetoric, Sino-US competition

$\mathrm{S}$ peculation intensified during the immediate post-Cold War period that the United States had become a unipolar power. At present, however, the notion of US unipolarity has become sharply tested on the basis of America's protracted involvement in, and material resources drain resulting from, the Iraq War (2002-2011), the global war on terror, and the US attack on the Islamic State of Iraq and Syria. Among regions in the world, the United States' unipolar position has been most strongly challenged in East Asia due to the rapid rise of China, which is physically located in the region. Robert Ross (1999) argues

*Jae Jeok Park (jjpark@hufs.ac.kr) is an assistant professor at Hankuk University of Foreign Studies. His research interests include alliance politics, US security policy in the Asia-Pacific, the US-ROK alliance, and the US-Australia alliance. He received his B.A and M.I.S. from Yonsei University, M.A. and M.S. from Northwestern University, and Ph.D. from Australian National University in 2009. He has published scholarly articles in Pacific Review, Asian Survey, Australian Journal of International Affairs, International Relations of Asia-Pacific, Korean Journal of Defense Analysis, Pacific Focus, International Area Studies Review, Asian Security, and Asian Studies Review. This work was supported by the Hankuk University of Foreign Studies Research Fund of 2017. 
that geography will cause China and the United States to divide the sphere of influence between continental states and maritime states. Also, Hugh White (2013) argues that while the United States will not accept China challenging its primacy in the region, regional states should envision a regional order in which the United States cooperates in a 'concert of power' with China. Moreover, David Kang (2003) sees regional states to be increasingly bandwagoning with China and suggests that a reconstitution of the old hierarchical Asian order centering on China is underway, providing a basis for regional stability.

Yet, the prospects for any of the above scenarios occurring anytime soon seem remote. First, the United States is not likely to retreat from the region, ceding regional strategic predominance to Beijing, despite the Trump administration's 'neo-isolationist' approach to foreign policy. Rather, as manifested by its recent re-emphasis on the spatial term 'Indo-Pacific,' the United States asserts that it will continue to provide intellectual direction and material resources to its allies and security partners in order to preserve and promote such values as the rule of law and freedom of navigation of the seas and airspace. Second, there is much resistance within the region to a hierarchical order led by China. Japan especially would not take comfort in such an order. Japan claims that it will assume a greater security role in the region by allowing itself to exercise the rights of collective self-defense. Third, China has been engaged in territorial and political disputes with its neighbors, while the United States does not harbor territorial ambitions in the region because it is physically located outside the region.

Under such circumstances, optimists about the stability of East Asia argue that the United States' continued commitment as a hegemon in the region and a significant improvement in a number of important bilateral relations will lead to a stable security environment. However, pessimists argue that the narrowing of the so-called "power gap," especially in light of China's rising status vis-a-vis the United States, will invariably have a destabilizing effect.

It is in this context that this article examines how far China now pushes ahead with its 'sphere of influence' ambitions and how determined the United States has been in preserving the US-led hegemonic order so as not to relinquish its interests or influence in the region. To do so, this article first investigates China's 'delegitimizing rhetoric' aimed at undermining a US-led regional order as a means of its balancing behavior against the United States at a low level. By presenting an alternative vision of order, China at the moment avoids the hard balancing against the United States it might do were its military capabilities closer to those of the United States, its fellow G-2 state. Nonetheless, it has begun to challenge the US-led order at the lowest level. Second, as a case study this article looks into the US strategy of strengthening its alliances and security 
partnerships in the Asia-Pacific or Indo-Pacific, which has been an essential component of the US-led strategy to preserve its hegemonic position in the region, and China's response to it. From a Chinese perspective, US strategy is intended to export US ideologies, such as values related to democracy and free trade, to encircle China. In response, China has been promoting the concepts of a 'new type of great power relations,' a 'new Asian security,' 'new type of international relation,' and a 'community of common destiny' as de-legitimating rhetoric against the US-led order in East Asia. Also, it frames the US attempts to strengthen US-led alliances and security partnerships as outright containment of China and advocates for a 'new regional security cooperation architecture' that excludes the United States.

On the other hand, if these projections between the United States and China proceed unchecked, regional states may have to brace for an era of tension and confrontation. Indeed, as Sino-US strategic competition has intensified, the two giants have been more often pressing regional states to choose between their rhetorical claims. For example, the United States has been asking regional partners to assert their stance on the freedom of navigation or the rule of international law in the South China Sea, which China perceives as a scheme of the United States to justify its power projection in the region against China. On the other hand, China has been pressing regional states to join China-initiated institutions under the name of developing an 'Asian regionalism' distinct from the existing west-centered one. China's push for South Korea's membership in the Asia Infrastructure Investment Bank (AIIB) is a good illustration, while the United States perceives the AIIB to be an institution that would weaken the USled World Bank or Japan-led Asia Development Bank. In this sense, the third part of the article examines how regional states have been attempting to carve out their space in the rhetorical confrontation between the United States and China in order to avoid being trapped in a war of rhetoric between the two great powers.

\section{'DELEGITIMIZING RHETORIC' AIMED AT UNDERMINING THE HEGEMONIC ORDER}

According to hegemonic stability theory, as the gap in capabilities between a hegemonic power and a rising power narrows, war is more likely to occur because (1) the hegemonic power has incentives to initiate a preventive war, or (2) the rising power militarily challenges the hegemonic state in order to assume a position in the international order commensurate with its budding ability to 
project power (Gilpin 1981). The question then becomes how much narrower it needs to be to eventuate conflict. However, setting aside judgment on the validity of various theories on when war is most likely to occur (Dicicco and Levy 1999), this article's sole focus is on the situation whereby a rising power is not yet strong enough to challenge the hegemon militarily.

Under such circumstances, balance-of-power theorists argue that the rising power will engage in "soft balancing," which is defined as balancing through the use of non-military means (Pape 2005, 7-11; Paul 2005, 58-70). While calling soft balancing a "practice of resistance," Schweller and Pu (2011, 47-49) argue that a rising power begins its balancing behavior at a lower level by undermining the legitimacy of the status quo international system supported by the hegemonic power. That is, they claim that a rising power engages in "a de-legitimating rhetoric (the discourse of resistance)" of presenting a competing vision of a new hegemonic order as a first step toward balancing against the hegemon, as the former is assumed not to yet have the material military capabilities to engage in full-fledged balancing behavior, including the use of military force, against the latter (Ibid.).

China has adopted this strategy of using de-legitimizing rhetoric in its relationship with the United States. Though the current fifth generation leadership favors the slogans of xiăokāngshèhuì (小康社会, “moderately prosperous society”) and Zhōngguó mèng (中國夢, “Chinese Dream”), it is as yet an aspiration rather than a concrete policy goal when it comes to Sino-US strategic competition, at least on the military front. It will take some time before China's growth will reach a point at which the United States would contemplate a preventive war against this rising power. Currently, the Xi government finds it more pressing to resolve its domestic problems than to divert available resources for an unnecessary zero-sum type of strategic confrontation with the United States.

Provided that China continues to rise while successfully managing to resolve its domestic problems, the power gap between the United States and China is likely to become narrower as time passes. Nevertheless, at present China has not reached the point at which power transition theory would likely predict a challenge to the hegemon. According to the SIPRI Military Expenditure Database, the United States spent $\$ 611$ billion on defense in 2016, which is the largest military budget in the world and higher than those of the next seven countries combined. China spent the equivalent of $\$ 215$ billion (SIPRI 2018; Peterson Foundation 2018).

Indeed, China perceives itself to be a rising developmental state rather than a G2 state comparable to the United States (Tiankai and Tepperman 2013). 
Under such circumstances, China indeed understands that it has limitations and shortcomings in competing for a leadership role against the United States, whether among the continental states in the region or for the entire region (Ibid.) Though China will maintain a policy stance of youssuo zuowei (有所作䋒, "getting one's interests aggressively") to guard its core interests, it is not yet in a position to pursue the stance of fen fa you wei (奮發有爲, "striving for achievement”) or duo duo bi ren (咄咄逼人, “threatening and overbearing”) against the United States (Swaine 2017). Rather, within the context of Sino-US relations, China still projects itself as doing heping jueqi (和平崛起 "peaceful rise”), if not taoguang yanghui (派光養晦 “biding one's time while building up capability").

That being said, China as a rising power will increasingly challenge the USled hegemonic order in the region. China's proclaimed concepts of a 'new type of great power relation,' 'the new Asian security,' 'the new type of international relation,' and a 'community of common destiny,' with the latter two being emphasized in the recent 19th Party Congress held in October 2017. Such slogans can be understood as what Schweller and Pu called a "de-legitimating rhetoric" against the US-led order in the Asia-Pacific. With the concept of a 'new type of great power relation' and a 'new type of international relation,' China claims that the existing superpower and the rising power should cooperate with each other in order to avoid the kind of hegemonic war that traditional Western international relations theories would predict. The concept is utilized to criticize the strengthening of the US-led security network that China perceives to be an outmoded relic of the Cold War.

Second, the concept of a 'new Asian security' and a 'community of common destiny' also are themes of a Chinese discourse aimed at de-legitimizing USled multilateralism in the region (Liff 2018). In the Asia-Pacific, multilateral security cooperation has been underdeveloped because of the lack of a sense of political community and shared political identity. Instead, the United States has maintained, and can continue to maintain, its hegemonic position (with its emphasis on democracy and free trade) through a combination of bilateral alliances and 'soft' multilateral ties (Fontaine 2017).

The region has witnessed the tension rise between a US-led inclusive AsiaPacific and a China-supported exclusive East Asian multilateralism. With regard to regional multilateral gatherings, China has been supporting exclusive East Asian groupings as opposed to inclusive Asia-Pacific groupings. In 2014, President Xi proposed a 'new regional security cooperation architecture' in his speech at the Conference on Interaction and Confidence Building Measures in Asia, which envisioned the building of a Pan-Asian multilateral order, to include 
Russia and Iran but not the United States (Liff 2018). It was the first time that a Chinese leader officially mentioned the term 'security cooperation architecture,' and the first White Paper released by China's Foreign Ministry in 2017 reiterated that term (Panda 2017). By proposing to create a regional security architecture that excludes the United States, China aims to disturb the US-led Asia-Pacific, or emerging Indo-Pacific, multilateral order.

As a case study, this article examines US justification for the US-led alliance and security network in the Asia-Pacific region and China's rhetorical response to it. The United States has been upgrading its alliances with Asian partners and creating various sets of linkage among the United States, its allies, and its security partners. Also, while facilitating mini-lateralism, the United States has been promoting a manufactured spatial concept of an 'Indo-Pacific' security region. The United States claims that such a US posture is necessary to maintain American leadership, which has been essential to stabilizing regional order. In contrast, China perceives these policies as part of a strategy to encircle China, and so the Chinese are challenging that leadership with 'de-legitimizing rhetoric (the discourse of resistance)' in company with 'practices of restraint' vis-à-vis the US.

\section{US LEGITIMATION FOR STRENGTHENING THE US-LED SECURITY NETWORK}

Since after World War II, the United States has been operating the so-called 'hub-and-spoke' alliance network in the Asia-Pacific region, which comprises its bilateral alliances with Australia, Japan, the Philippines, South Korea, and Thailand. In operating the hub and spoke alliance network in the post-Cold War period, the United States has been strengthening individual alliances and facilitating mini-lateral linkages of the alliances through multilayered bilateral processes, as was clearly manifested in the Obama administration's 'rebalancing to Asia' strategy. The United States claims that it has been doing so because, above all, systematic cooperation among the 'spokes' is needed in order to respond effectively to new and emerging non-traditional security issues in a post-Cold War security landscape. The Trilateral Strategic Dialogue (TSD) among the United States, Japan, and Australia is a good illustration. The three states adopted non-traditional security issues as the main agenda of the TSD and have been conducting joint military exercises. The United States has also been seeking linkages between the US-Japan and the US-South Korea alliances, as was clearly reflected in the remarks of then-Assistant Secretary of State for East 
Asian and Pacific Affairs Kurt Campbell before the Senate Foreign Relations Committee in March 2011 when he stated, "[The US] will take ambitious steps to increase trilateral cooperation to further develop a more integrated Northeast Asia security architecture" (Campbell 2011). It is in that context that the United States urged Japan and South Korea to sign the General Security of Military Information Agreement (GSOMIA) in 2016. From the US perspective, the South Korea-Japan GSOMIA is a first step towards linking the US-South Korea and US-Japan alliances and further creating a 'virtual alliance' relationship between the spokes of South Korea and Japan (Park 2012). Though the South Korean government has been reluctant to establish stronger linkages between the two alliances, the United States has continued to exert pressure to link the US-Japan and the US-South Korea alliances. In terms of the US-led alliances in Southeast Asia and the Pacific since the end of the Cold War, the United States has tended to invite third parties when it conducts joint military exercises with its ally. Indeed, the annual military exercises of the US-Philippines and the US-Thailand alliances increasingly have been conducted in a multilateral setting (Ibid.). Other ad-hoc military exercises for counter-terrorism and disaster relief have mostly been conducted in a multilateral format as well.

The United States also has been attempting to expand mini-lateral linkages to include India. For example, US-Japan-India trilateralism was launched in 2007 at a track-2 level, and since 2011, at a track-1 level (Green 2014). Moreover, the idea of expanding the TSD to a quadrilateral security dialogue (QSD) that includes India has been revived, as was clearly indicated in the Trump administration's National Security Strategy released in December 2017. Such an idea was first initiated by Japan and supported by the United States in 2007, when both Japan and Australia participated in the regular naval military exercise between the United States and India known as Malabar. Yet the idea was shelved, as Australia distanced itself from committing to what China perceived as a strategy of outright containment. However, the idea of the QSD has been revived, as the three states have been increasing security interactions with India. To illustrate, Japan participated in Malabar in 2009, 2014, and 2015, and has been doing so every year since 2016. The United States has become the most frequent state with which India has conducted military exercises (Miglani 2017). Australia had been reluctant to join Malabar out of consideration for China, but it has been reported that Australia expressed interest in joining the 2017 exercises (Smith 2017). Though India objected to Australia's participation in Malabar, the two countries recently have been conducting bilateral military exercises right before or after the Malabar exercises.

Some argue that, based on Trump's 'neo-isolationist' approach to foreign 
policy, Washington might gradually withdraw from its engagement in the AsiaPacific, thereby seriously challenging the Obama administration's emphasis on constructing what Ash Carter described as a "principled security network" (Carter 2016). However, since President Trump approaches foreign policy issues from the perspective of a businessman using cost-benefit analysis, his administration has been sustaining the military aspect of the Obama administration's rebalancing strategy to Asia because it is a more cost-effective way to deal with regional security issues than any alternative. First of all, in a network structure, the United States can establish a division of labor among itself and the network's component states more definitively. Second, the United States should be in a better position to inform and spread rules, norms and regulations of the 'operating system' to the component states of the network, and to verify whether they are complying with those new rules, norms, and regulations. Third, the United States can reduce transaction costs in coordinating collective action with its allies and security partners. Indeed, in his Asia trip in November 2017, President Trump "reiterated that the network of American alliances remains in place, and that (America) is not stepping away from them" (Cheng 2017).

With the revival of the idea of the QSD came the spatial concept of the IndoPacific. The concept originated from a "broader Asia' fashioned out of the confluence of the Pacific and Indian Oceans," which was proposed by Japanese Prime Minister Shinzo Abe in 2007 (Chacko 2014, 443). The United States considers the Indo-Pacific as part of a new security area larger than the AsiaPacific, as clearly stated by then-US Secretary of State Hillary Clinton in 2011 (Chacko 2014) and most recently by President Trump during his Asia trip in November 2017. From the US and Japanese perspectives, the Indo-Pacific is a space wherein a group of democratic states can work together to prevent an exclusively China-centered regionalism from coming into fruition.

The United States and its allies cite 'alliance mutuality' as the glue that links them together. William Tow and Amitav Acharya $(2007,27)$ define alliance mutuality as "collective or shared interests and values that cut across different alliances, particularly bilateral ones, to reinforce cooperation throughout an entire network of alliances". Those interests include maintaining a benign US offshore balancing role for regional stability, and the values include democracy, human rights, free trade, and freedom of navigation.

That being said, it is hard to deny that a strengthened US alliance network also functions as a hedge against potential Chinese threats. In particular, China has been closely watching the aforementioned expansion and deepening of USJapan-Australia trilateral security cooperation (Liff 2018). China suspects that, ultimately, the United States will likely form a small-scale Asia-Pacific version 
of NATO to contain China by incorporating India into the US-Japan-Australia tripartite arrangement. Pan $(2013,452)$ argues that the spatial term of 'IndoPacific' is a discursive reflection of "anxieties about China's rise in the Asian regional order". No matter how the United States intends to create a 'free and open' Indo-Pacific, Washington justifies the use of this expanded concept by citing such values as the rule of law, freedom of navigation, and free trade shared among the four potential security partners (US Department of State 2017).

\section{CHINA'S RESPONSE WITH 'DE-LEGITIMIZING' RHETORIC'}

From a Chinese perspective, the US-led alliance and security network exports US ideologies, or such values as democracy, freedom of navigation, and rule of law, to justify the US-dominated regional hegemonic order at the expense of China's national interests (Fang and Ma 2014). In response, China has been confronting the United States with 'de-legitimizing (the discourse of resistance)' rhetoric along with 'practices of restraint' (soft-balancing).

First, in terms of a 'de-legitimizing rhetoric,' China emphasizes the concept of a 'new type of great power relation,' which then-Vice President Xi Jinping proposed in 2012. The concept of 'the new type of great power relation' was reiterated during the 19th Party Congress held in October 2017, though it was reworded as 'the new type of international relation' (Swaine 2017).

China has been referring to these concepts to criticize the strengthening of the US-led alliance network, which China perceives as an outmoded relic of the Cold War. Indeed, the slogan of 'the new type of great power relation' came out around the early 2010s, when the Obama administration adopted the 'rebalancing strategy' toward Asia. China frames US attempts to form linkages among alliance partners as an attempt to contain China, thereby going against the concept. According to the concept, the United States and China should cooperate with each other in order to avoid a war between them that power transition theory would predict. In order to overcome a typical security dilemma in which the United States and China condemn each other as the cause of the Sino-American strategic confrontations, they should highlight their complementary aspects and reconcile with each other. Fu Ying, chair of the Foreign Affairs Committee of the National People's Congress of China, goes so far as to assert that China has been pursuing cooperative security rather than the US-led collective security. She maintains that the former is necessary to "grow out of the zero-sum mentality of the Cold War, and it is China's answer to the U.S.-led 'collective security' mechanism," which is informed by a zero-sum mentality (Fu 2017). 
Second, China has been developing a 'de-legitimizing rhetoric' of panAsianism to counter the expansion of the US-led alliance network under the name of what China considers a manufactured spatial term, 'Indo-Pacific.' With respect to the regional space, China finds an exclusively East Asian regionalism more conducive to its national interests, as it can wield more influence without the presence of the United States, Australia, and New Zealand. For example, China had hoped to confine the membership of the East Asian Summit to ASEAN+3 states when it was inaugurated in 2005. However, as inclusive AsiaPacific regionalism prevailed over exclusive East Asian regionalism, as in the case of APEC, ARF and EAS, China now is attempting to establish a multilateral order that includes Southeast Asian and Middle Eastern states, while excluding the United States.

Third, China has been challenging the aforementioned US justification for expanding and deepening the US-led alliance and security network. From the Chinese perspective, the United States came up with the rhetoric of 'containing communism' during the Cold War in order to create and consolidate the US-led alliance network in East Asia. With the demise of the Soviet Union, however, the United States lost the essential rationale for retaining the US-led alliance network in the Asia-Pacific, as well as in Europe. To reflect the changing security environment, the rationale the United States adopted in the post-Cold War era has been to promote democracy and preserve free trade, values embedded in the US-led liberal order. As the United States retains its alliances in the AsiaPacific region and extends its security network, Washington may well replace that rationale with a new one. First, the United States supports the US-Thailand alliance despite the fact that there have been a series of military coups that led to the overthrowing of a democratically-elected government. Also, although the ways Philippine President Rodrigo Duterte has been conducting his war on drugs are far from democratic, the United States has been maintaining the USPhilippines alliance since he took office. Thus, promoting democracy now cannot act as the rhetorical glue holding together the US-led alliances. Second, the United States has been developing security relationships with non-democratic states. The United States has remarkably enhanced its security relationship with Singapore, whose regime type is authoritarian. Furthermore, the United States has been approaching Vietnam and Myanmar to increase security cooperation with them. Neither state is democratic. In all, promoting democracy can no longer serve as the aforementioned 'alliance (or security) mutuality.' Under such circumstances, China argues that the United States has now been advertising the rule of law and a 'free and open Indo-Pacific' as the new pretext for preserving the US-led alliance and security network and taking advantage of territorial 
disputes between China and several regional states such as Vietnam and the Philippines. Therefore, China has been seeking to de-legitimize the rule of law rhetoric put forward by the United States. China frames it as a disguised US justification for strengthening the US-led alliance and security network in order to better contain China. To do so, China asserts that there is no consensus in the region regarding who should make the law on what.

China has accompanied this de-legitimizing rhetoric with economic investment as a part of a 'practice of restraint' so that China can persuade domestic and international audiences to buy into the rhetoric. China also has been setting up international development and security institutions and inducing regional states to join them, while framing their participation as choosing China's rhetoric visà-vis that of the United States'. A case in point is China's idea of constructing two new Silk Road routes. President Xi proposed a 'silk road economic belt' in his speech at Nazarbayev University in Kazakhstan in September 2013. Reestablishing these transportation routes was proposed to enhance economic cooperation between China, East Asia, and the Middle East. President Xi also proposed a 'maritime silk road' in his speech to Indonesia's Parliament in October 2013; one that would span Southeast Asia, South Asia and the Middle East. The two proposals are economically very attractive to countries along the Silk Road route. China claims that stakeholder states should set up a bank to provide funds for the infrastructural development necessary to implement the proposals. In doing so, China asserted that bank membership should be given only to Asian states, while excluding the United States. China built this pan-Asian multilateral institution to court Asian states to help set up the AIIB. The bank was then widely regarded as a Chinese-led Asian development bank as opposed to the US-led World Bank or Japan-led Asia Development Bank. While the United States expressed its concern over South Korea joining the organization, President Xi officially asked then-South Korean President Park Geun-hye to join it as one of the founding states during a summit between the two held in July 2014. South Korea did indeed join in March 2015. China hosted a conference on the Belt and Road Initiative in 2016, and the Chinese Communist Party enshrined the initiative into its constitution during the Party Congress in 2017. China also is likely to further develop a 'de-legitimizing rhetoric' of pan-Asianism to counter the concept of an 'Indo-Pacific' security corridor through its offer of economic incentives to regional states.

Notably, China has been increasing economic investment in several Southeast Asian countries. After a series of confrontations with regional states in claiming its 'core interests' in the South and East China Seas, China has come to realize that the United States has been exploiting regional states' fears of an 
aggressive China as a means of inducing them to cooperate with the US policy of strengthening the US-led alliance and security network. For example, on the shoulders of territorial disputes between China and the Philippines, the United States and the Philippines signed the Enhanced Defense Cooperation Agreement in April 2014, which enables the former to have access to, and use of, Philippine military facilities at the latter's discretion.

Since coming to such a realization, China has been taking a more nuanced approach with respect to other East Asian states. Bilaterally, it has been increasing economic investment in several East Asian countries, especially ones along the Mekong River, with the intention of inducing them to represent China's interests in regional multilateral gatherings. For example, China is the largest investing country in Cambodia. In light of this, it is notable that Cambodia, as chair of the 2014 ASEAN foreign ministers' meeting, refused to produce a joint statement condemning China's assertive behavior in the South China Sea, despite strong requests made by the Philippines and Vietnam. As a result, the ASEAN ministerial meeting failed to produce a joint communiqué for the first time in its 45-year history. It is not coincidental that China has increased investment in Laos and the Philippines, which chaired ASEAN meetings in 2016 and 2017, respectively.

The more China develops 'de-legitimating discourses' in combination with 'practices of restraint' against the US-led regional order, the more often both the United States and China will push regional states to choose between their rhetorical claims. In that context, the following section looks into how regional states have been attempting to mark out their own space under such circumstances.

\section{REGIONAL STATES' RESPONSES}

There are variations of how regional states have responded to China's 'delegitimizing rhetoric' aimed at undermining the US-led alliance and security network. Japan, North Korea, and Russia have already taken clear sides between the United States and China, and they have taken advantage of the Sino-US rhetorical war to enhance their security interests. Other states, mostly US allies and security partners, have attempted to develop a region-wide discourse for promoting regional bilateral, mini-lateral, and multilateral cooperation independent of Sino-US geostrategic competition because they need to pursue a more nuanced approach to protect both their security partnership with the United States and their economic interests in China. 
Japan has been exploiting the United States' strengthening of its alliance and security network, and China's negative response to it, to push to become a more 'normal' state. Japan's exploitation is grounded in the fact that the biggest constraint on the United States in pursuing a rebalancing to Asia strategy is the lack of material resources. As a way of burden sharing with its allies, the United States has been inducing regional allies to assume a greater role in dealing with regional security issues, while the United States acts in a more supportive role. Japan's attempt to exercise its right for collective self-defense lines up perfectly with US strategic interests. Noting that the United States welcomes and appreciates Japan's greater security commitment in the region, Japanese policy-makers have adopted more nationalistic responses to regional historical and territorial issues; responses that sometimes diverge from US positions on those issues.

With respect to the rhetorical confrontation between the United States and China, Japan has fully supported the United States. For example, Japan proposed the concept of a 'broader Asia' in 2007, which then-US Secretary of State Hillary Clinton reframed as the 'Indo-Pacific.' Japan suggested the expansion of the TSD to a QSD that included India as a 'democratic' alliance and justified the emergence of an 'Indo-Pacific' security area as essential to the preservation of the rule of law and freedom of navigation from the Indian Ocean to the Pacific.

On the other hand, North Korea has also been exploiting the United States' strengthening of its alliance and security network and China's negative response to it in order to advance its development of nuclear weapons and long-range missiles. China worries that, if North Korea collapsed, China would lose its strategic buffer, as US forces in Korea would likely eventually be stationed near the Chinese border in a Korea unified under the South. Also, if the two Koreas were unified on South Korea's terms, the United States would attempt to pressure China to adopt such values as democracy and human rights through a unified Korea. It would be a destabilizing factor to a Chinese government that is based on a political monopoly by the Communist Party. Unless China fully implements economic sanctions on North Korea, Pyongyang believes it can survive the current international sanctions regime against it, so the North continues to conduct nuclear and missile tests. China has been participating in UN-led sanctions condemning North Korea's nuclear and missile tests. However, as long as China is placed in a position of balancing against the United States, whether in a soft form or in a hard form, North Korea will take advantage of the Sino-US geostrategic competition, engaging in continued military adventurism. In that context, North Korea will continue to portray the United States as an imperialistic aggressor or a malignant hegemon and side with China in the 
latter's rhetorical war against the United States.

Russia also has taken advantage of the situation. Russia has been losing its influence in East Asia, as it has been preoccupied with tackling domestic economic problems. There seems to be no effective way to restore Russia's influence in the region in the near future. For example, though it is a member of the Six Party Talks, the Six Party Talks' inactive status prevents Russia from raising a voice in Northeast Asian security matters. For Russia, Sino-US geostrategic competition provides it with time to bite the bullet to get its own economic house in order. Overall, the emphasis of Russia's East Asian policy is on maintaining stability in the region and creating a multilateral collective security system, as the country hopes to prevent any superpower from attaining primacy. In the meantime, Russia welcomes China's active role in checking expansion of the US-led order. This is not to say that Russia does not harbor any fear of China's rise. Indeed, Russia worries about the increase in China's population and its investment in the Siberian region. Nevertheless, Russia has been increasing its cooperation with China at a time when it has had to take further measures following its military annexation of Crimea from the Ukraine. Russia's shift to China is to help counter-balance Western states' isolation of Russia over the Crimea issue. For example, in addition to small-scale military exercises China and Russia been have conducting since 2003 as part of the Shanghai Cooperation Organization (SCO), they also have been engaging in large-scale bilateral military exercises since 2012.

Unlike Japan, North Korea, and Russia, most of the regional states do not benefit from a US strategy of strengthening its alliances and security partnerships in the Asia-Pacific to contain China (or at least something that China perceives as such). Those other states also do not benefit from supporting China's attempts to delegitimize the US-led order by engaging in the 'discourse of resistance.' In such circumstances, those states would be forced to take sides between the two.

As Sino-US strategic competition has intensified, most regional states have been walking a fine line between China and the United States and hoping not to be placed in a situation of having to choose between the two. US allies and security partners especially have stated that they would be pursuing a more nuanced approach to strike a balance between their security partnership with the United States and their economic interests in China. The former serves as the backbone of their security, while the latter has become increasingly important, as China has become the region's largest trading partner. However, it is not an easy task to harmonize security policy so that China is not uneasy with the strengthened security relationship that regional states have with the United 
States, while not making Washington uneasy by increasing their strategic and cooperative relationships with China. For example, given North Korea's WMD, conventional capabilities, and unpredictable political situation, South Korea may well maintain and strengthen its alliance with the United States. On the other hand, in order to stop North Korea's WMD programs and to achieve unification of the two Koreas, South Korea sees Chinese and US support as essential. Also, South Korea has substantial and ever-growing economic interests in China. It is in this context that South Korea hopes to expand military cooperation with China starting at a low level under the theme of a 'strategic cooperative partnership,' including mutual visits of high-ranking military officers. At the fourth Vice Ministerial Defense Strategic Dialogue held in July 2014, the two states agreed to establish military hotlines between defense ministers. Though a product more of ambition than reality at this stage, especially in the aftermath of the THAAD controversy between China and South Korea, the current South Korean government may attempt to enhance security cooperation with China to the level of holding joint military exercises under the name of dealing with nontraditional security threats.

US allies and security partners prefer the transparency and market-driven economics embedded in the values undergirding the US-led order to an uncertain and untested China-led regional order. Thus, regional states have tried not to fall into a Chinese trap of delegitimizing the US-led order. They do not agree with the Chinese concepts of 'the new type of great power relation,' 'the new Asian security,' 'the new type of international relation' and 'the new neighbor-centric foreign policy.' At the same time, those regional actors with security ties to the United States do not want China to perceive the maintenance of the US-led order as a part of a strategy of China's encirclement. This being the case then, regional states should develop an area-wide discourse for promoting regional bilateral, mini-lateral, and multilateral cooperation, independent of Sino-US geostrategic competition. Neither the United States nor China is in a position to moderate such a discourse. If the two states tried to do so, their real intentions would be questioned by those regional states.

To develop regional rules and norms that would eventually put an end to a traditional zero-sum type brand of geo-politics, regional states have to be at the forefront of regional multilateral initiatives. For example, former South Korean President Park Geun-hye proposed the 'Northeast Asia Peace and Cooperation Initiative' (NAPCI). The NAPCI was based on the belief that, if regional states accumulated practices of cooperation in issue areas in which it was relatively easy to elicit agreement and cooperation among them, they then could build trust based on those practices. The trust built among those states would serve 
as a foundation upon which they might build cooperation in more difficult issue areas. That is, the NAPCI aimed to enhance functional cooperation in 'soft' security issues, such as disaster relief, environmental protection, nuclear safety, anti-terrorism, climate change, disease control, transnational crime, and cyber terrorism, in order to build the trust necessary for cooperation on harder, traditional security issues, such as territorial disputes.

In line with the NAPCI, South Korea's incumbent president, Moon Jae-in, launched a multilateral diplomatic initiative called the 'Northeast Asia Plus Community of Responsibility' (NAPCOR). It aims to "alleviate the security dilemma caused by the U.S.-China strategic rivalry, expand the external links, diversify and intensify issues, and pursue institutionalization through multilateral cooperative diplomacy led by South Korea" (Kim 2017, 3). Indeed, the NAPCI and the NAPCOR evolved from similar peace initiatives proposed by South Korea and other regional states, reflecting the current regional security situation. South Korea proposed the 'Consultative Conference for Peace in Northeast Asia' during the Roh Tae Woo administration, the 'Northeast Asia Security Dialogue' during the Kim Young-sam administration, the 'Era of Peace and Prosperity in Northeast Asia' during the Roh Moo Hyun administration, and the 'New Asia Initiative' during the Lee Myung Bak administration.

Outside of South Korea, a few states have made similar proposals, including Australia's 'Asia-Pacific Community' in 2008, Japan's 'East Asia Community Initiative' in 2009 and Mongolia's 'Ulaanbaatar Dialogue on Northeast Asian Security' in 2013. None of these proposals have been implemented, mostly due to the lack of support from regional states other than the proposing state. However, the more seriously China challenges the US-led order with a 'discourse of resistance,' the more regional states will feel a certain urgency to establish a regional identity and a sense of community. Otherwise, a new Cold War-type of security confrontation between the US-led alliance network and a nascent China-led bloc has the potential to expand. That is why these initiatives warrant more attention from regional states.

\section{CONCLUSION}

Although economic interdependence among all Asia-Pacific states has been expanding rapidly, security cooperation remains underdeveloped. The former South Korean President Park termed the discrepancy in the levels of cooperation over economics compared to security issues as the "Asia Paradox." This paradox is made clearer when comparing Asia to Europe, which has achieved a high 
level of political integration and formed multilateral security mechanisms for collective defense. At the center of this Asia paradox is the geo-strategic competition between the United States and China. Washington has been strengthening the US-led alliance and security network, claiming the necessity of maintaining 'American leadership,' which has been an essential component in stabilizing regional order. In contrast, China perceives US efforts as an outright policy of China's containment, and it has responded by balancing against the United States with 'de-legitimizing rhetoric (the discourse of resistance)' in concert with 'practices of restraint.'

China's attempts to de-legitimize the US-led order cannot avoid incurring costs. In order for "a de-legitimating rhetoric (the discourse of resistance)" to be successful, China has to "grow socially within the existing international society" and regional states will have to recognize that growth (Schweller and $\mathrm{Pu} 2011,56)$. Taking advantage of that point, several regional states have been pushing China to abide by international norms and rules, especially with respect to China's territorial disputes with several Southeast Asian states over control of the South China Sea, and to China's response to North Korea's military provocations and WMD developments. Furthermore, regional states are proactively developing regional rules and norms that transcend the dialectic tug of war between the US pursuit of liberal values and China's delegitimizing rhetoric against that US-led order. Regional multilateral initiatives led by various regional states, including South Korea's NAPCI and NAPCOR, can be understood as integral parts of such efforts.

\section{REFERENCES}

Campbell, Kurt. 2011. "U.S. Policy Toward North Korea: Remarks." US Department of State. Accessed at https://2009-2017.state.gov/p/eap/ $\mathrm{rls} / \mathrm{rm} / 2011 / 03 / 157472 . h t m$ (January 31, 2018).

Carter, Ash. 2016. "The Rebalance and Asia-Pacific Security: Building a Principled Security Network.” Foreign Affairs 95, 65.

Cheng, Dean. 2017. "Scoring Trump's Big Adventure in the Indo-Pacific." The Heritage Foundation (November 17). Accessed at http://www.heritage. org/asia/commentary/scoring-trumps-big-adventure-the-indo-pacific (January 30, 2018).

Chacko, Priya. 2014. "The Rise of the Indo-Pacific: Understanding Ideational Change and Continuity in India's Foreign Policy." Australian Journal of International Affairs 68(4), 433-452. 
Dicicco, Jonathan and Jack Levy. 1999. "Power Shifts and Problem Shifts." Journal of Conflict Resolution 43(6), 675-704.

Fang, Guangshun and Ma Quiang. 2014. "Strategy of Rebalance to the AsiaPacific in Obama's New Term and US Ideological Export.” In Xing Qu ed., China's New Diplomacy and the Changing World. Beijing: World Affairs Press.

Fontaine, Richard, Patrick Cronin, Mira Rapp-Hooper, and Harry Krejsa. 2017. Networking Asian Security: An Integrated Approach to Order in the Pacific. Washington, D.C.: Center for a New American Security.

Fu, Ying. 2017. "China's Vision for the World: A Community of Shared Future." The Diplomat (June 22). Accessed at https://thediplomat. com/2017/06/chinas-vision-for-the-world-a-community-of-sharedfuture/ (January 30, 2017).

Gilpin, Robert. 1981. War and Change in World Politics. New York, NY: Cornell University Press.

Green, Michael. 2014. "Strategic Asian Triangles." In Saadia Pekkanen, John Ravenhill, and Rosemary Foot eds., The Oxford Handbook of the International Relations of Asia. Oxford, UK: Oxford University Press.

Kang, David. 2003. "Getting Asia Wrong: The Need for New Analytic Frameworks." International Security 27(4), 57-85.

Kim, Joon Hyung. 2017. "The Moon Administration's Multilateral Regional Diplomacy: An Initiative of Northeast Asia Plus Community of Responsibility." ROK Angle 165. Accessed at http://www.kida.re.kr/ $\mathrm{cmm}$ /viewBoardImageFile.do?idx=23519 (January 31, 2018).

Liff, Adams. 2018. "China and the US Alliance System." The China Quarterly 233, 137-165.

Miglani, Sanjeev. 2017. "Indian Navy the Odd Man Out in Asia's 'Quad' Alliance." Reuters (November 22). Accessed at https://www.usnews. $\mathrm{com} /$ news/world/articles/2017-11-22/indian-navy-the-odd-man-outin-asias-quad-alliance (January 31, 2018).

Pan, Chengxin. 2013. "The 'Indo-Pacific' and Geopolitical Anxieties about China's Rise in the Asian Regional Order." Australian Journal of International Affairs 68(4).

Panda, Ankit. 2017. "The Future of the Asia-Pacific Security Architecture, as Seen by China." The Diplomat. Accessed at https://thediplomat. com/2017/o1/the-future-of-the-asia-pacific-security-architecture-asseen-by-china/ (January 31, 2018).

Pape, Robert. 2005. “Soft Balancing Against the United States." International Security 30(1), 7-45. 
Park, Jae Jeok. 2012. "Cost-Benefit Analysis of the South Korea-Japan General Security of Military Information Agreement (GSOMIA)." Online Series Co 12-26, Korea Institute for National Unification. Accessed at http://www.kinu.or.kr/www/jsp/prg/api/dlV. jsp? menuIdx $=315$ \&category $=3$ o\&thisPage $=1 \&$ biblioId $=1449878$ (January 31, 2018)

Paul, T.V. 2005. "Soft Balancing in the Age of U.S. Primacy." International Security 30(1), 46-71.

Peterson Foundation. 2018. "Selected Charts on the Long-Term Financial Challenges of the United States." Accessed at http://www.pgpf.org/ sites/default/files/PGPF-Chart-Pack.pdf (January 31, 2018).

Ross, Robert. 1999. "The Geography of the Peace: East Asia in the TwentyFirst Century." International Security 23(4), 81-118.

Schweller, Randall, and Xiaoyu Pu. 2011. "After Unipolarity: China's Visions of International Order in an Era of US Decline.” International Security 36(1), 41-72.

SIPRI. 2018. Military Expenditure Database. Accessed at https://www.sipri. org/databases/milex (January 30, 2018).

Smith, Jeff. 2017. "Why is India Excluding Australia from Naval Drills?" The Diplomat. Accessed at https://thediplomat.com/2017/o6/why-isindia-excluding-australia-from-naval-drills/ (January 30, 2018).

Swaine, Michael. 2017. "The $19^{\text {th }}$ Party Congress and Chinese Foreign Policy." Carnegie Endowment for International Peace (October 26). Accessed at http://carnegieendowment.org/2017/10/16/19th-party-congress-andchinese-foreign-policy-pub-73432 (January 30, 2018).

Tiankai, Cui, and Jonathan Tepperman. 2013. "Beijing's Brand Ambassador: A Conversation with Cui Tiankai." Foreign Affairs 92(4), 10-17.

Tow, William, and Amitav Acharya. 2007. Obstinate Or Obsolete?: The US Alliance Structure in the Asia-Pacific. Canberra, Australia: Department of International Relations, Research School of Pacific and Asian Studies, Australia National University.

US Department of State. 2017. "Australia-India-Japan-U.S. Consultations on the Indo-Pacific.” Press Statement. Accessed at https://www.state.gov/ $\mathrm{r} / \mathrm{pa} / \mathrm{prs} / \mathrm{ps} / 2017 / 11 / 275464 . \mathrm{htm}$ (January 31, 2018).

White, Hugh. 2013. The China Choice: Why We Should Share Power. Oxford, UK: Oxford University Press.

[Received Feb 1, 2018; Revised Apr 16, 2018; Accepted May 3, 2018] 
